\title{
Global Business Networks and Cooperation within Supply Chain as a Strategy for High-Tech Companies' Growth
}

\section{Milena Ratajczak-Mrozek}

\begin{abstract}
The specificity of the operation profile of high-tech companies, including the necessity of operating at the international scale may account for the fact that these companies may find in network relationships, business networks and cooperation an essential determinant for growth and competitiveness. Foreign entities should be especially interesting business partners for hightech companies, as they are often seen as representing more advanced knowledge, resources and experience. The aim of the article is to point out to global business networks (i.e. including both local and foreign entities), and especially to cooperation within supply chain, as an important basis for a growth strategy of a high-tech company.

The article adopts assumptions of the network approach as a concept of companies cooperation. An analysis of the author's own as well as secondary empirical research, with the focus on hightech companies located in Poland is presented. In particular, the data from own research of 62 high-tech companies in Poland conducted in the first half of 2011 is analysed. It shows that the high-tech companies placing great importance on cooperation within supply chain demonstrate a higher growth and level of competitiveness than the companies which do not ascribe such importance (bearing in mind that supply chain forms an important part of a business network). Keywords: high-tech companies, high-technology companies, industrial network, business network, network approach, cooperation, supply chain management, competitiveness, company performance, growth strategy
\end{abstract}

\section{Introduction}

Due to globalisation of competition and fast rate of changes occurring in micro- and macro environment, high-tech companies may not reach satisfactory benefits if they shut out cooperation and limit their strategies to internal development of technology. Moreover, a question arises whether in the face of growing interrelations between entities, internationalisation of operation and the rate of technology development, such shutting out of high-tech companies is possible at all?

Milena Ratajczak-Mrozek, PhD, Poznań University of Economics, Department of International Marketing, milena.ratajczak@ue.poznan.pl. 
More and more often the necessity of cooperation and developing partnerships (relationships) with external entities, which can significantly influence a company's success, is emphasized in research (see Wilson and Mummalaneni, 1986, p. 44-58; Fonfara, 2009, p. 3). In network relationships, global business networks and cooperation companies may find an essential determinant of growth and competitiveness. Of all the groups of entities with which companies may cooperate, the biggest attention is paid to those constituting links in supply chain (see Gadde and Snechota 2000, p. 305316; Hollensen, 2003, p. 197-254; Golicic 2007, p. 719-739; Barry, Dion and Johnson 2008 , p. 114-135). And precisely this strategy, i.e. concentration on global business networks, and especially cooperation within supply chain, may bring satisfying results to high-tech companies and ensure their growth and competitiveness.

The aim of the article is to point out to global business networks, and especially to cooperation within supply chain, as an important basis for a growth strategy of a high-tech company. In order to attain this goal, the article presents an analysis of the author's own as well as secondary empirical research, with the focus on high-tech companies located in Poland.

\section{Global business networks and supply chains - theoretical background}

The network approach is a concept of cooperation of companies which was conceived in late 1970s. This concept stresses the significance of all the contacts (network relationships) a company has with the entities in its surrounding environment. Breakthrough outlooks in this field were presented by the scientists connected with Industrial Marketing and Purchasing Group (IMP Group) (http://www.impgroup.org/). A network relationship is a general phenomenon that persists over a longer time and is developed through interactions between entities (Easton, 1992, p. 4). All the company's relationships constitute an extended network - a business network (an industrial network).

The literature of the subject points to two theoretical trends relating to the emergence of business networks - the network approach consistent with the main IMP Group research stream and the concept of strategic business network.

According to the network approach consistent with the main IMP Group research stream, a business network is constituted by a collection of long-term formal and informal relationships (direct and indirect) which exist between two or more entities (Håkansson and Snehota, 1989). Within the considered framework, a system of relationships is often characterised as being decentralized and informal. The business network is an effect of historical cooperation, whilst through cooperating and a series of interactions, entities adjust to each other, create cooperation norms and build trust. Usually none of the entities plays a dominant role (Turnbull, Ford and Cunningham, 1996, p. 44-62; Ford, Håkansson and Johanson, 1986, p. 26-41).

Companies, increasingly frequently, consciously, and in a strategic manner, create business networks concentrated around them. These types of relationships illustrate the strategic approach to the development of network relationships. The strategic 
approach (D'Cruz and Rugman, 1993; Jarillo, 1995) stresses active and conscious development of a network of relationships and the presence of one main entity (flagship firm) intentionally building a strategic network. The main characteristic of relationships between the partners of a network is the asymmetric and strategic control exercised by one flagship company over the remaining (independent or "slightly" dependent) companies. The focal company specialises in areas of the value chain in which it is most competent. The remaining necessary resources are sourced from other entities via subcontracting or outsourcing. The flagship firm only has strategic control over those aspects of its partners' business systems which are dedicated to the network. Over time, the participants of the strategic business network adapt their behaviour to that of other partners, thereby expanding cooperation to include informal links, too (Jarillo, 1988, p. 31-41).

It must be underlined that both of the approaches regarding the creation of business networks are not opposed to each other. These approaches should be considered as complementary (Ratajczak-Mrozek, 2010, p. 14-15). Moreover, the literature pertaining to industrial marketing indicates a wide range of companies' cooperation concepts connected with the idea of business network. It is shown that cooperation can be developed in clusters (DeBresson, 1996, p. 161), joint ventures, strategic alliances (Ancarani and Shankar, 2003, p. 2-3), logistics networks (Wimmer, Mandják and Esse, 2010, p. 2-3), virtual organizations (Anderson, Håkansson and Johanson, 1994, p. 1) etc. A detailed analysis, however, reveals that each of the identified structures constitutes a specific type of a business network, enriched by additional assumptions or, in some cases, considered from the perspective of a dyadic relationship (Ratajczak-Mrozek, 2010, p. 16-21; Anderson et al., 1994, p. 1-2).

Network relationships may be established and maintained at the local level, the country level or broader - at the international level encompassing foreign entities. According to the network model of internationalisation, the process of company's internationalisation is defined as the establishment, maintenance and development of formal and informal relationships with network participants on foreign markets (Johanson and Mattsson, 1988, p. 287). This model stresses the importance of developing long-term interactions with entities from the foreign environment (Blankenburg, 1995). In case the relations are extended beyond the local, country framework, the networks become global networks, i.e. networks including also foreign entities.

The idea of a strategic network can be linked to the concept of logistics networks and supply chain. The supply chain can be defined as a network of connected and interdependent organisations which act on the basis of joint cooperation, jointly control, manage and improve the resource and goods flows from suppliers to the final consumer. Therefore, supply chain constitutes a fragment of the overall subject of business networks. Encompassing foreign entities, supply chain is a selected, limited in terms of its objects, fragment of a general global business network. 
Research carried out to date devotes most of its attention precisely to the vertical network relationships between customers and suppliers within supply chain (see: Håkansson, Johanson and Wootz, 1976, p. 319-332; Ford, 1984, p. 101-113; Gadde and Snechota, 2000, p. 305-316; Hollensen, 2003, p. 197-254; Golicic, 2007, p. 719-739; Barry, Dion and Johnson, 2008, p. 114-135). This is a result of more intense cooperation between companies and entities forming their supply chain as opposed to other entities in their environment (such as competitors, influential entities). Additionally, this might be linked to more clearly visible positive effects which can be tied to network relationships within supply chain (also at the international scale). That is the reason why particular attention should be in fact given to the analysis of relationships and network relationships between entities within supply chain.

\section{Conceptual framework}

The term "high technologies" encompasses areas and products which are characterised by high R\&D intensity and additionally a high level of innovativeness, short life cycles of products and processes, fast diffusion of innovations, a growing demand for highly qualified staff (especially in the field of technical and natural sciences), great capital outlays, high investment risk (and fast "ageing" of investment), close scientific and technical cooperation (within individual countries and on the international arena, between companies and research institutions), and growing competition in international trade (Niedbalska, 1999, p. 98).

The clear specificity of the operation profile of high-tech companies, resulting from the quoted definition, is the reason why in the case of these entities, due to short life cycles and usually long development period of products, the ability to gain advanced knowledge, broaden the technological base, and reduce costs and risk becomes important, and this indeed may be secured by cooperation and business networks (see European Commission, 2003, p. 9).

On the other hand, internationalisation of high-tech companies operations may be perceived to be not a matter of choice, but a necessity. Domestic market creates too limited demand for products offered by these companies which have to be quickly commercialised (Madsen and Servais, 1997, p .561-583; Spence, 2003, p. 227). The more so is international orientation necessary for small and medium-sized high-tech companies, i.e. for their growth and long-term survival (Karagozoglu and Lindell, 1998). It seems that the necessity of operating at the international scale together with the rest of the specificity of operation of high-tech companies is the reason why foreign entities should be especially interesting business partners for these companies. Due to different location, business environment and experience, these entities possess different knowledge (often perceived to be more advanced) and different resources. For this reason cooperation with these entities should be measurably beneficial to high-tech companies.

Taking into consideration the specificity of high-tech companies, a conceptual research framework was developed based upon the above presented interrelations 
between global business networks and supply chain. It embraces three elements: global business networks and high-tech company's relationships with different local and foreign entities; cooperation and relationships within supply chain; and, finally, the company's growth and competitiveness as important elements of a growth strategy of high-tech company (see Figure 1).

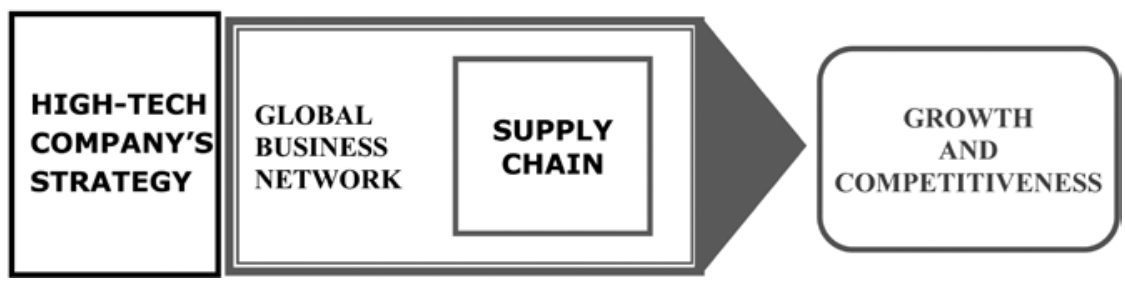

Figure 1. Conceptual Framework

A high-tech company operates within a global business network maintaining various relationships with different types of local and foreign entities (suppliers, customers, subcontractors, influential entities, competitors). Supply chain and vertical relationships play a significant role as part of a business network. The analysis below places a special emphasis on these relationships and high-tech company's cooperation within supply chain.

It is assumed that the above-mentioned interrelations and including them in a strategy is important for the high-tech company's growth and competitiveness. Business networks and cooperation are not the sole factors influencing the company's growth; however, the analysis aims to indicate a certain tendency and to point out the importance of global business networks.

The further parts of the article firstly present a theoretical analysis and previous research based on the author's own and secondary data concerning global business networks and cooperation within supply chain as an important basis for the growth strategy of high-tech companies. Secondly, taking for the basis the conclusions from previous research, an analysis of the most recent author's own research concerning cooperation of high-tech companies within supply chain and the role of this cooperation in the growth and competitiveness of the discussed companies is presented.

\section{Global business networks and cooperation within supply chain as a source of growth and competitiveness of high-tech companies - the analysis of previous research}

\section{Benefits from global business networks}

Business networks and network relationships require a new look at the issue of the company's growth and competitiveness which has to take into account the effects of relationships and many interrelations between business entities. The existence of 
global business networks may be a source of many potential benefits for a high-tech company, which in turn may contribute to its growth and competitiveness. Amongst the important benefits from building relationships within global business networks and cooperation, there would be the following (Glabiszewski and Sudolska, 2009, p. 17; Gorynia and Jankowska, 2008, p. 136; Plawgo, 2005, p. 21; Ratajczak-Mrozek, 2012, p. 54-72; Sudolska, 2008, p. 109):

- access to resources and capabilities,

- access to knowledge,

- increasing the innovativeness of the company and its products,

- cost reduction,

- reducing operational risk,

- increasing bargaining power against other entities,

- the benefits of specialisation,

- economies of scale and increased market range (at the local and international scale).

Amongst the above-mentioned benefits the issues of resources and knowledge deserve special emphasis as regards high-tech companies. Network relationships enable acquisition of resources which are at partners' disposal and also give ability to obtain resources unavailable thus far to any of the parties. It is straightforwardly stressed that resources which are difficult to duplicate cannot be obtained through ordinary market transactions, but through an exchange within the network relationship framework (Ring, 1996, p.10). Thanks to foreign network relationships, companies are open to both domestic and foreign external resources. The research confirms that amongst high-tech companies in Poland mutual supplementation of resources (and especially technology) is a popular form of interrelations between companies of diverse competence and capabilities (Włosiński, Szerenos, 2006, p. 85). On the other hand, the research from New Zealand suggests that high technology companies, which increase their resource base through external relation networks, attain a higher sales growth (Wilson and Appiah-Kubi, 2002, p. 54-59).

In the case of high-tech companies, sometimes straightforwardly called knowledge intensive firms, knowledge is especially important (Johnson, 2004, p. 139154). Knowledge is of particular importance for the competitiveness of companies, since their unique integration is the factor that can differentiate a company. The company's learning processes are amplified in particular by network relationships (Johansson, 2001, p. 23; Håkansson, Havila and Pedersen, 1999 pp. 443, 450). The research confirms that in the case of companies within the biotechnology sector in Poland, the imperative factor inducing companies to cooperate is the craving for knowledge. Another important reason for establishing cooperation is conduct of research on new products and technologies (Żelazko, 2009, p. 98). Empirical data also confirms that large innovative projects are developed, managed and commercialised within business networks rather than by single enterprises (European Commission, 2003, p. 38). 
Owing to the exchange of resources and knowledge within global business network, it is possible to increase the innovativeness of the company and its products. In order to maintain the competitive advantage on international markets, high-tech companies must have technological advantage (Li, Lam and Qian, 2000, p. 457). At the same time, the growing correlation between previously independent technologies makes it more and more difficult for the companies to develop them on their own (Contractor, Kim and Beldona, 2002, p. 496). Cooperation constitutes a significant factor in the process of discovery, application and diffusion of innovation (OECD, 2000, p. 38). Vertical relationships (with suppliers and customers) (Håkansson, Lundgren, 1995, p. 307-309) and horizontal relationships (with research institutes, competitors or complementary companies) (Håkansson and Lundgren 1995, p. 308; Thomas and Ford, 1995, p. 271), as well as social networks (Davies and Koza, 2001, p. 95-102), influence the company's innovation. In turn, innovation is crucial for the company's growth and competitiveness (Drucker, 1985; Kay, 1993), even more under global competition conditions.

Global business networks and network relationships may additionally have a positive effect, among other things, on the course of production and logistic processes inside the company, which together contribute to an increase in effectiveness, increasing bargaining power against other entities, as well as to cost minimisation and risk reduction. Thanks to local and foreign relationships, a company may specialise in business activities in these areas of the value chain which allow it to obtain competitiveness to the greatest degree (Cravens, Piercy, Shipp, 1996, p. 204; Christopher, Payne and Ballantyne, 2002, p. 121).

The benefits of global business networks related to the expansion of high-tech companies should also be noted. This refers both to gaining new local customers and to expansion on foreign markets through relationships with foreign entities, i.e. company's internationalisation. Research (Kennedy and Keeney, 2006; Schwens and Kabst, 2006) confirms that in the case of high-tech companies cooperation is an important mechanism of entering foreign market, which enables them to accelerate the sales cycles and reduce the risk. Moreover, it should be noticed that the processes of competitive strategy internationalisation as well as the new sources of its competitiveness occur alongside the process of extending company's operation to new markets. Thus internationalisation generates potential for the company's growth (Sapienza, Autio, George and Zahra, 2006, p. 919-920). As a result of extending operation to new markets, a growth in sales volume may occur. This in turn contributes to achieving economies of scale through increasing the scale of production and makes it possible to avoid the negative effects of shortening the high-tech product life cycle.

In order to benefit from global business networks for a long-term and in a possibly sustainable manner, a strategic approach to building these networks is necessary. In one word, global business networks and cooperation must become a permanent strategy basis.

The research conducted in 2007 on a sample of 74 high-tech companies (RatajczakMrozek, 2010) proved that $76 \%$ of the surveyed high-tech companies, which actively 
built network relationships with foreign entities, achieved financial and non-financial results which were better than these of their closest competitors. For the sake of comparison, amongst the companies which were passive in terms of building network relationships and business networks, only as few as $58 \%$ of companies declared achievement of better results. Furthermore, the thesis that the achievement of competitive advantage by high-tech companies is connected with active and conscious building of network relationships was also positively verified in terms of statistical regression.

In that research the relative differences in financial and non-financial performance were studied based on a consolidated formula including profit, sale volume, return on investment (ROI), and market share. Using the Likert scale the respondents were to provide their own self-assessment of these measures in relation to the closest competitors. At the same time, it should be remembered that active building of network relationships is not the only factor having a bearing on the results achieved by the surveyed high-tech companies, nevertheless, the observed trend enabled confirmation of a positive influence of active and conscious building of network relationships on the results achieved by these companies.

\section{Positive effects of cooperation within supply chain}

Of all the groups of entities with which companies (both high-tech and representing traditional sectors) may cooperate, attention is mostly paid to these constituting links in supply chain (see Gadde and Snechota, 2000, p. 305-316; Hollensen, 2003, p. 197254; Golicic, 2007, p. 719-739; Barry, Dion and Johnson, 2008, p. 114-135). Moreover, the research confirms that vertical links (between customers and suppliers) are more often developed among high-tech companies located in Poland than horizontal links (between competitors or institutions of research or education), which concerns both cooperation with national (Włosiński and Szerenos, 2006) and foreign entities (Ratajczak-Mrozek, 2010; Włosiński, Szerenos, 2006). Generally, companies continue to cooperate with each other within the framework of supply chain more and more often.

The great importance attached to cooperation with entities within supply chain is connected with positive results, which are faster and more directly noticed and which may be connected with cooperation within supply chain (in the form of, for instance, reduction of costs or increase in the volume of orders placed by customers). The direct effects of cooperation with other types of entities may be more difficult to point out or may manifest in a longer period.

Development of close relationships with customers is a key area of companies' operation, especially on business to business (B2B) markets (Fonfara 2004, p. 80, 116121). Close cooperation with customers offers a wide range of benefits to companies. Firstly, it enables reduction of service costs. The retention of existing customers is much cheaper than winning new ones. Additionally, it enables the development of a product offer tailored to individual needs of customers thanks to including them in 
product development processes. It also facilitates the development of customer loyalty (Hollensen, 2003, p. 202-223). In turn, cooperation with suppliers can lead to a significant reduction of costs thanks to the implementation of appropriate logistic solutions, just-intime delivery or joint product improvements etc. (Hollensen 2003, p. 223-231).

The empirical analysis of 74 high-tech companies carried out in 2007 confirmed that high-tech companies which perceived their results better than these of their competitors utilised the relations established within the supply chain more intensively (RatajczakMrozek, 2010).

On the other hand, the analysis of the data from the simulation experiments carried out in 2012 showed that it is more profitable for high-tech companies to collaborate with enterprises which have greater capacities and can offer greater supply, which reduces the number of supply chains. (Kawa, Ratajczak-Mrozek, 2012). This analysis was carried out on the basis of a developed model based on the graph theory, the business network concept and the competitiveness indicator (an average of the four results - profit, market share, sales volume and ROI). Four tiers of enterprises have been distinguished. The first tier was represented by a high-tech flagship company followed by assemblers, suppliers, and factories. The flagship company initiates the configuration of supply chain which is induced by the final customer. Therefore, it was assumed that supply chains were created for the needs of a specific transaction induced by the customer's demand.

\section{Cooperation within supply chain versus competitiveness and growth of companies - empirical research}

\section{Data collection and sample characteristics}

Data was obtained from a survey conducted between February and June $2011^{[1]}$. The questionnaire was sent by mail. The address list was prepared on the basis of a national data base by the company Kompass Poland. The dataset included companies representing all industries from all over Poland, including high-tech companies. The sample was selected randomly, which made it possible to generalise on the whole population. Out of 192 answers the data concerning high-tech companies operating abroad has been chosen. The paper presents the data concerning 62 high-tech companies.

Delimitation of high-tech sector is based on the concept of industry and the name "high-tech" is given to companies (production and service) which belong to selected industries in accordance with the Eurostat classification. These industries are: manufacture of basic pharmaceutical products; manufacture of office machinery and computers; manufacture of radio, television and communication equipment and apparatus; manufacture of medical, precision and optical instruments, watches and clocks; manufacture of aircraft and spacecraft; post and telecommunications; and information technology.

1 The Research Project "Development of business networks in a company internationalization process" financed by Poland's Ministry of Science and Higher Education, 2010-2012, project leader K. Fonfara. 
Almost $80 \%$ of the research sample was made up of micro, small and mediumsized enterprises (according to the criterion of 249 employees), whilst:

- $50 \%$ were medium enterprises,

- $22.5 \%$ - small enterprises,

- $6.5 \%$ - micro enterprises.

The remaining $21 \%$ were large and very large enterprises. Private entities definitely dominated (over $90 \%$ of the sample). The size and ownership structure of the surveyed companies is consistent with the structure of the entire Polish high-tech industry, which is mainly made up of small and medium-sized enterprises.

The characteristic of the surveyed high-tech companies in terms of the course of their internationalisation process is interesting. It is so much important as the further presented analysis concerns cooperation of high-tech companies with foreign entities, i.e. in the aspect of operation on the global market. Most of the surveyed companies (72\%) have run international operation for at least 3 years, meaning that they already have some experience as regards activity on the international arena and that they should have proper experience in contacts with foreign entities.

Undoubtedly the applied forms of internationalisation are dominated by direct export $(67.7 \%$ of the surveyed companies), subcontracting $(43.5 \%)$, and indirect export (30.6\%). Each time non-capital and capital cooperation as well as own direct investments are carried out by less $15 \%$ of the analysed high-tech companies . In the future the analysed companies plan to turn towards more advanced forms of internationalisation (an increase in non-capital and capital cooperation, and direct investments) and turn away from the forms which to a less degree encompass advanced knowledge transfer (especially indirect export and subcontracting).

\section{Data analysis}

The first stage of the analysis includes the analysis of an average assessment of the importance attached by all surveyed high-tech companies to cooperation with particular types of foreign entities from the perspective of the companies' performance (see Table 1).

Table 1. The importance of cooperation with particular types of foreign entities for the high-tech companies performance

\begin{tabular}{lc}
\hline \multicolumn{1}{c}{ Entities } & Score \\
\hline Customers & 4.38 \\
Suppliers & 3.95 \\
Competitors & 2.61 \\
Business agents & 3.38 \\
Influential entities & 2.73 \\
\hline
\end{tabular}

Answer scale: 1 - hardly important, 2 - little important, 3 - no opinion, 4important, 5 - very important 
On average vertical cooperation within successive links of supply chain (suppliers, business agents, and customers) is of the greatest importance for the achieved results amongst all the analysed high-tech companies. On the other hand, influential entities and competitors get the lowest assessment. These results are compatible with the general trend observed on the market and confirmed by previous research, whilst in this case they relate not so much to the fact of cooperation itself as to its effects.

The next stage of the analysis deals with identification of company groups with varying approaches to cooperation within supply chain. The division is carried out based upon the analysis of responses pertaining to the assessment of the importance of the significance ascribed to cooperation with various foreign entities within supply chain for the company's performance. An average assessment of the importance of cooperation with three types of foreign entities is taken into account: customers, suppliers, and business agents. This is the basis for distinguishing two groups within the analysed high-tech companies:

- SCHigh, i.e. companies ascribing great importance for their performance to cooperation within supply chain (an average assessment of cooperation with customers, suppliers and subcontractors $\geq 4.0$ ), 34 companies in total;

- SCLow, i.e. companies ascribing little importance for their performance to cooperation within supply chain (an average < 4.0), 27 companies in total.

The two distinguished groups represent a relatively similar number, which is important in view of further analysis and making comparisons.

Taking into account the two groups of high-tech companies with different approaches to the assessment of the importance of the significance ascribed to cooperation with various entities within supply chain for their performance, an attempt to verify whether these approaches have any bearing on the growth and competitiveness of these companies can be made.

With a view to assessing the growth and competitiveness of the companies, financial and non-financial company's performance indicators, which cover profit, return on investment (ROI), sales volume and market share achieved by the respondents, were analysed:

- in 2010 compared with 2007 (the analysis of growth),

- in 2010 compared with these of the closest competitors (the analysis of competitiveness).

Due to the difficulties in comparing companies with different characteristics (taking into account such elements as size, ownership, and industry), a subjective assessment method of comparison was adopted based upon the relative assessment of the companies themselves. The application of such an evaluation method facilitates the comparison of companies with different characteristics in terms of their overall performance. The adaptation of this evaluation method is based upon the earlier research (Fonfara, 2010; Fonfara, 2012).

The 5-point Likert scale was used for the assessment. The respondents, by answering the questions in the questionnaire relating to four aspects of their 
performance (profit, ROI, sales volume, and market share) were to provide their own self-assessment in relation to their closest competitors or the year 2007 (1 - considerably worse, 2 - worse, 3 - almost the same, 4 - better, 5 - considerably better). A score above 3.0 means that the company deemed its performance to have been better than this of its competitors or recorded a performance growth (compared to 2007). It should be noted that due to the applied scale the relative differences in rating may seemingly appear to be rather small. It is, however, largely caused by a small dispersion of the minimum and maximum rating $(1-5)$.

Table 2 presents the average results for the above-mentioned financial and non-financial indicators of high-tech companies' performance in terms of growth and competitiveness and the division by the two indicated varying approaches to cooperation within supply chain.

Table 2. Financial and non-financial indicators of high-tech companies' performance in terms of growth and competitiveness

\begin{tabular}{lcccc}
\hline \multicolumn{2}{c}{ Performance indicator } & \multicolumn{2}{c}{ SCHigh } & \multicolumn{2}{c}{ SCLow } \\
& N & Score & N & Score \\
\hline \multicolumn{2}{c}{ Growth (performance indicators in relation to year 2007$)$} \\
Profit & 29 & 3.76 & 25 & 3.52 \\
ROI & 29 & 3.52 & 25 & 3.20 \\
Sales volume & 29 & 3.66 & 25 & 3.56 \\
Market share & 29 & 3.52 & 25 & 3.52 \\
Average of four performance indicators & 29 & 3.62 & 25 & 3.45 \\
Competitiveness (performance indicators in relation & to the closest competitors) \\
Profit & 20 & 3.85 & 19 & 3.37 \\
ROI & 20 & 3.60 & 19 & 3.05 \\
Sales volume & 21 & 3.57 & 19 & 3.21 \\
Market share & 22 & 3.45 & 20 & 3.20 \\
Average of four performance indicators & 20 & 3.62 & 18 & 3.21 \\
\hline
\end{tabular}

$\mathrm{N}$ - The number of responses regarding the specific performance indicator

Answer scale: 1 - considerably worse, 2 - worse, 3 -almost the same, 4 - better, 5 - considerably better

The results presented in the above table indicate a very distinct trend. In terms of both growth (in relation to 2007) and competitiveness (in relation to the closest competitors), within each of the analysed performance indicators, the high-tech companies ascribing great importance for their performance to cooperation within supply chain (SCHigh) achieve higher results compared to the companies ascribing little importance to this cooperation (SCLow). The only exception is the market share, where both analysed groups record the same results, meaning that the analysed high-tech companies ascribing great importance to cooperation within supply chain demonstrate a higher growth as well as the level of competitiveness than the companies, which do 
not ascribe such importance (of course, from the perspective of their own assessment of the performance).

The carried out analysis confirms that cooperation within supply chain is an important basis for the strategy aimed at assurance of growth and competitiveness of high-tech companies. At the same time, it should be repeated that cooperation within supply chain is not the sole factor influencing the company's growth. However, the analysis aims to confirm a certain tendency, and not statistical interrelations.

\section{Conclusions and further research}

The analysis carried out in the article proved that global business networks, and especially cooperation within supply chain, is an important basis for the growth strategy of high-tech companies, bearing in mind that supply chain forms an important part of a global business network. The necessity for treating cooperation and building network relations at a global scale as permanent elements of the strategy should be stressed. Only such approach to cooperation and global business networks may assure possibly sustainable growth.

However, the analysis is not free of certain limitations, which simultaneously suggest further areas of study. First of all, the questions connected with the adopted industrial criterion of high-tech companies' delimitation arise. Although it is a generally adopted criterion, which is most useful in surveys, one should be aware that the category of "industry" is broad enough to encompass individual companies applying technologies which are advanced to various degrees, and companies characterised by different degrees of innovativeness or involvement in research and development. There is a possibility that technologically advanced companies are found outside the listed industries and, on the other hand, not much technologically advanced entities are encountered within them. Secondly, it would be important that further research encompass a comparison of the results of the presented analysis with the answers of companies representing traditional industries, which would enable one to show how specific the indicated solutions are to solely high-tech industries.

It may be anticipated that the issues connected with cooperation and global business networks will be more and more important, both in economic practice and in the cognitive sphere, hence it is crucial to continue research in this area.

\section{References}

Ancarani, F., Shankar, V. (2003), Strategic Alliances And Customer Interactions In Convergent Industries, Paper presented at the 19th IMP-conference, Lugano, Switzerland.

Anderson, J., Håkansson, H., Johanson, J. (1994). Dyadic Business Relationships Within a Business Network Context. Journal of Marketing, 58 (10).

Barry, J.M., Dion, P., Johnson, W. (2008). A Cross-Cultural Examination of Relationship Strength in B2B Services. Journal of Services Marketing, 22 (2). 
Blankenburg, D. (1995). A network approach to foreign market entry. In: K. Möller, D.T. Wilson (Eds.), Business marketing: an interaction and network perspective. USA: Kluwer Academic Publishers.

Christopher, M., Payne, A., Ballantyne, D. (2002). Relationship marketing. Creating stakeholder value. Oxford: Butterworth Heinemann.

Contractor, F.J., Kim, C., Beldona, S. (2002). Interfirm Learning in Alliance and Technology Networks: An Empirical Study in the Global Pharmaceutical and Chemical Industries. In: F.J. Contractor, P. Lorange (Eds.), Cooperative strategies and alliances. Amsterdam-Tokyo: Science.

Cravens, D.W., Piercy, N.F., Shipp, S.H. (1996). New Organizational Forms for Competing in Highly Dynamic Environments: the Network Paradigm. British Journal of Management, 7 (3)

Davies, P.N., Koza M.P. (2001). Eating soup with a fork: how informal social networks influence innovation in high-technology firms, Strategic Change, 10 (2).

DeBresson, C. (1996). Why innovative activities cluster. In: C. DeBresson (Ed.), Economic Interdependance and Innovative Activity. An Input-Output Analysis. Cheltenham: Brookfield.

D'Cruz, J.R., Rugman, A.M. (1993). Developing international competitiveness: the five partners model, Business Quarterly, 8 (2).

Drucker, P. (1985). Innovation and entrepreneurship: practice and principle. London: Butterworth-Heinemann.

Easton, G. (1992). Industrial Networks: a Review. In: B. Axelsson, G. Easton (Eds.), Industrial Networks. A New View of Reality, UK: Routledge.

European Commission (2003). Observatory of European SMEs 2002- High-tech SMEs in Europe. European Commission.

Fonfara, K. (2004). Marketing partnerski na rynku przedsiębiorstw. Warszawa: Polskie Wydawnictwo Ekonomiczne.

Fonfara, K. (Ed.) (2009). Zachowanie przedsiębiorstwa w procesie internacjonalizacji. Podejście sieciowe. Warszawa: Polskie Wydawnictwo Ekonomiczne.

Ford, D. (1984). Buyer-Seller Relationships in International Industrial Markets. Industrial Marketing Management, 13 (2).

Ford, D., Håkansson, H., Johanson, J. (1986). How Do Companies Interact?. Industrial Marketing and Purchasing, 1 (1).

Gadde, L.E., Snechota, I. (2000). Making the Most of Supplier Relationships. Industrial Marketing Management, 29 (4).

Glabiszewski, W., Sudolska, A. (2009). Rola współpracy w procesie kształtowania konkurencyjności przedsiębiorstwa. Organizacja i Kierowanie, 2.

Golicic, S.L. (2007). A comparison of shipper and carrier relationship strength. International Journal of Physical Distribution \& Logistics Management, 37 (9).

Gorynia, M., Jankowska, B. (2008). Klastry a międzynarodowa konkurencyjność $i$ internacjonalizacja przedsiębiorstwa. Warszawa: Difin. 
Håkansson, H., Havila, V., Pedersen, A.C, (1999). Learning in Networks. Industrial Marketing Management, 28 (5).

Håkansson, H., Johanson, J., Wootz, B. (1976). Influence Tactics in Buyer-Seller Processes. Industrial Marketing Management, 5.

Håkansson, H., Lundgren, A. (1995). Industrial networks and technological innovation. In: K. Möller, D.T. Wilson (Eds.), Business marketing: an interaction and network perspective, USA: Kluwer Academic Publishers.

Håkansson, H., Snehota, I. (1989). No business in an island: the network concept of business strategy. Scandinavian Journal of Management, 5 (3)

Hollensen, S. (2003). Marketing Management. A Relationship Approach. Harlow: Financial Times Prentice Hall.

Jarillo, J.C. (1988). On Strategic Networks. Strategic Management Journal, 9 (1).

Jarillo J.C. (1995). Strategic networks. Creating the bordless organization. USA: Butterworth Heinemann.

Johansson, M. (2001). Searching the known, discovering the unknown, The Russian Transition from Plan to Market as Network Change Process. Uppsala: Uppsala Universitet.

Johanson, J., Mattsson, L.G. (1988), Internationalisation in Industrial Systems - A Network Approach. In: N. Hood, J.E. Vahlne (Eds.), Strategies in Global Competition, New York: Croom Helm.

Johnson, J.E. (2004). Factors Influencing the Early Internationalization of High Technology

Start-ups: US and UK Evidence. Journal of International Entrepreneurship, 2 (1/2).

Karagozoglu, N., Lindell, M. (1998). Internationalization of Small and Mediumsized Technology-Based Firm: An Exploratory Study. Journal of Small Business Management, 36 (1).

Kawa, A., Ratajczak-Mrozek, M. (2012). Supply Chain Configuration in High-Tech Networks. In: J.-S. Pan, S.-M. Chen, N.T. Nguyen (Series editors), Lecture Notes in Artificial Intelligence LNAI 7196, (pp.459-468). Berlin Heidelberg: Springer-Verlag.

Kay, J. (1993). Foundations of corporate success. How business strategies add value. Oxford: Oxford University Press.

Kennedy, A., Keeney, K. (2006). Strategic partnerships and the internationalization process of software SMEs. Paper presented at the 32nd EIBA Annual Conference, Fribourg, Switzerland.

Li, J., Lam, K., Qian, G. (2000). High-tech industries and competitive advantage in emerging markets: a study of foreign telecommunications equipment firms in China. The Journal of High Technology Management Research, 10 (2).

Madsen, T.K., Servais, P. (1997). The internationalization of born globals: an evolutionary process?. International Business Review, 6 (6).

Niedbalska, G. and others (1999). Definicje pojęć z zakresu statystyki nauki i techniki, Warszawa: Główny Urząd Statystyczny.

OECD (2000). A New Economy? The changing role of innovation and information technology in growth. OECD. 
Plawgo, B. (2005). Przesłanki i formy powiązań kooperacyjnych przedsiębiorstw. In: B. Plawgo, W. Zaremba (Eds.), Partnerskie współdziałanie w sektorze publicznym i prywatnym, Białystok: Fundacja Współczesne Zarządzanie.

Ratajczak-Mrozek, M. (2010). Sieci biznesowe a przewaga konkurencyjna przedsiębiorstw zaawansowanych technologii na rynkach zagranicznych. Poznań: Wydawnictwo Uniwersytetu Ekonomicznego w Poznaniu.

Ratajczak-Mrozek, M. (2012). The premises for establishing business networks in the internationalisation process (research project 2010-2012). In: K. Fonfara (Ed.), The development of business networks in the company internationalisation process (pp. 71-81), Poznań: Poznań University of Economics Press.

Ring, P.S. (1996). Networked Organization, A Resource Based Perspective, Uppsala: Uppsala University.

Sapienza, H.J., Autio, E., George, G., Zahra, S.A. (2006). A capabilities perspective on the effects of early internationalization on firm survival and growth. Academy of Management Review, 31 (4).

Schwens, C., Kabst, R. (2006). How early internationalizers learn: experience of others and paradigms of interpretation. Paper presented at the 32nd EIBA Annual Conference, Fribourg, Switzerland.

Spence, M. (2003). International Strategy Formation in Small Canadian High-Technology Companies - A Case Study Approach. Journal of International Entrepreneurship, 1 (3). Sudolska, A. (2008). Stan i potrzeba współpracy przedsiębiorstw w Polsce. In: W. Popławski, A. Sudolska, M. Zastempowski, Współpraca przedsiębiorstw w Polsce w procesie budowania ich potencjału innowacyjnego, Toruń: Dom Organizatora.

Thomas, R., Ford, D. (1995). Technology and networks. In: K. Möller, D. T. Wilson (Eds.) Business marketing: an interaction and network perspective. USA: Kluwer Academic Publishers.

Turnbull, P.W., Ford, D., Cunningham, M. (1996). Interaction, relationships and networks in business markets: an evolving perspective. Journal of Business \& Industrial Marketing, 11 (3/4).

Wilson, D.T., Mummalaneni, V. (1986). Bonding and Commitment in Buyer-Seller Relationships: a Preliminary Conceptualisation, Industrial Marketing and Purchasing, 1 (3).

Wilson, H.I.M., Appiah-Kubi, K. (2002). Resource leveraging via networks by hightechnology entrepreneurial firms. The Journal of High Technology Management Research, 13 (1).

Wimmer, Á., Mandják, T., Esse, B. (2010). Perception and practice of the supplier relationship management. Paper presented at the 26th IMP Conference in Budapest, Hungary.

Włosiński, K., Szerenos A.M. (2006). Klastry wysokotechnologiczne na Mazowszu wyniki badań. Organizacja i Kierowanie, 3.

Żelazko, B. (2009)., Kooperacja firm biotechnologicznych w Polsce. Kwartalnik Nauk o Przedsiębiorstwie, 4. 
Abstract (in Polish)
Specyfika profilu działalności przedsiębiorstw high-tech (zaawansowanych, wysokich technologii), w tym konieczność aktywności w skali międzynarodowej, sprawiajq, że przedsiębiorstwa te mogq odnaleźć w kooperacji, relacjach sieciowych i sieciach biznesowych niezbędnq determinantę wzrostu i konkurencyjności. Szczególnie interesujgcymi partnerami biznesowymi dla nich powinny być podmioty zagraniczne, często postrzegane jako reprezentujq̨ce bardziej zaawansowanq wiedzę, zasoby i doświadczenie.

Celem artykułu jest wskazanie globalnych sieci biznesowych (czyli obejmujqcych podmioty lokalne i zagraniczne), a w szczególności kooperacji z podmiotami tworzq̨cymi łańcuch dostaw, jako istotnej podstawy strategii wzrostu przedsiębiorstw high-tech.

W artykule przyjęto optykę podejścia sieciowego (network approach) jako koncepcji współpracy przedsiębiorstw. Przedstawiono analize kilku zarówno własnych, jak $i$ wtórnych badań empirycznych, koncentrujq̨c się na przedsiębiorstwach high-tech zlokalizowanych w Polsce.

W szczególności zaprezentowano wyniki własnych badań przeprowadzonych wśród 62 przedsiębiorstw high-tech w Polsce w pierwszej połowie 2011 roku. Ukazano, że przedsiębiorstwa high-tech przypisujqce duze znaczenie współpracy $w$ ramach tańcucha dostaw wykazywały zarówno większy wzrost, jak i poziom konkurencyjności w porównaniu z przedsiębiorstwami nie przypisujqcymi dużego znaczenia tej współpracy (pamiętajq̨c przy tym że łańcuch dostaw stanowi ważna część sieci biznesowej). Podkreślono konieczność traktowania współpracy i kształtowania relacji sieciowych w wymiarze globalnym jako stałego elementu strategii przedsiębiorstw hightech. Tylko takie podejście do współpracy i globalnych sieci biznesowych może zapewnić możliwie trwały wzrost.

Słowa kluczowe: przedsiębiorstwa high-tech, sieci przemysłowe, sieć handlowa, podejście sieciowe, wspótpraca, zarzq̨dzania tańcuchem dostaw, konkurencyjność, wydajność spótki, strategia wzrostu. 